\title{
Surgical Treatment of Ampullary Adenocarcinoma - Single Center Experience and a Review of Literature
}

\author{
Chirurgická léčba ampulárního adenokarcinomu - \\ zkušenosti jednoho centra a přehled literatury
}

\author{
Kunovsky L. ${ }^{1}, 2$, Kala Z. ${ }^{1}$, Prochazka V. ${ }^{1}$, Potrusil M. ${ }^{1}$, Dastych M. ${ }^{2}$, Novotny I. ${ }^{3,4}$, Andrasina T. ${ }^{5}$, Pavlovsky Z. ${ }^{6}$, \\ Eid M. ${ }^{7}$, Moravcik P. ${ }^{1}$ \\ ' Department of Surgery, Faculty of Medicine, Masaryk University, University Hospital Brno, Czech Republic \\ 2 Department of Gastroenterology, Faculty of Medicine, Masaryk University, University Hospital Brno, Czech Republic \\ ${ }^{3}$ Department of Gastroenterology, Masaryk Memorial Cancer Institute, Brno, Czech Republic \\ ${ }^{4}$ Endoscopy Center, Faculty of Medicine, Masaryk University, University Hospital Brno, Czech Republic \\ ${ }^{5}$ Department of Radiology, Faculty of Medicine, Masaryk University, University Hospital Brno, Czech Republic \\ ${ }^{6}$ Department of Pathology, Faculty of Medicine, Masaryk University, University Hospital Brno, Czech Republic \\ ${ }^{7}$ Department of Hematology, Oncology and Internal medicine, Faculty of Medicine, Masaryk University, University Hospital Brno, Czech Republic
}

\begin{abstract}
Summary
Background: Adenocarcinomas of ampulla of the Vater are relatively uncommon tumors of the gastrointestinal tract. In premalignant lesions endoscopic treatment predominate. According to some authors even early adenocarcinomas (limited to mucosa) can be solved endoscopically. In malignant lesions affecting deeper layers (including submucosa) surgical therapy is the most important. The article summarises the current view for a surgical treatment of ampullary adenocarcinomas and presents results concerning our group of patients. Materials and Methods: In 2012-2016 a total number of 17 patients underwent resection for a tumor of ampulla of the Vater. Patients underwent standard staging, were presented before a multidisciplinary committee and referred to a surgical treatment. The main measured parameters were the type of surgical procedure, 30-day morbidity and mortality, histopathologic result and subsequent oncologic treatment. The Leeds Pathology Protocol was used to evaluate the specimens after pancreaticoduodenectomy (PD). Results: PD $(n=9)$ was a more often performed procedure than the transduodenal surgical ampullectomy $($ TSA $)(n=8)$. TSA predominated in polymorbid patients. Histological results $(n=17)$ established adenoma with high-grade dysplasia in 4 patients, the diagnosis of adenocarcinoma was set in 13 patients. Eight patients underwent adjuvant oncologic therapy ( 2 had adjuvant chemotherapy, 6 had combination of chemoradiotherapy). Conclusion: Premalignant neoplasias of ampulla of the Vater can be mostly solved by endoscopy. If endoscopic resection is not possible surgical therapy is indicated. PD is preferred procedure in the diagnosis of adenocarcinoma. In high-risk and polymorbid patients, with no suspicion for a metastatic lymph nodes, TSA can be considered. Endoscopic ultrasonography is the imaging modality of choice for local staging of ampulla of the Vater and has important role in deciding between endoscopic, local surgical excision (TSA) or radical resection (PD). Our results confirmed rightfulness to perform TSA especially in elderly or polymorbid patients, where in histopathologic specimens evaluation in TSA procedures early T stage and more favorable grading predominated.
\end{abstract}

Key words

adenocarcinoma of the ampulla of Vater - duodenum - endoscopic resection - ampullectomy - pancreaticoduodenectomy - surgery
Supported by Ministry of Health, Czech Republic - conceptual development of research organization (FNBr, 65269705) - SUp 14/16.

Podpořeno Ministrerstvem zdravotnictví ČR koncepční rozvoj výzkumné organizace ( $F N B r$, 65269705) - SUp 14/16.

The authors declare they have no potential conflicts of interest concerning drugs, products, or services used in the study.

Autoři deklarují, že v souvislosti s predmětem studie nemaji žádné komerční zájmy.

The Editorial Board declares that the manuscript met the ICMJE recommendation for biomedical papers.

Redakční rada potvrzuje, že rukopis práce splnil ICMJE kritéria pro publikace zasílané do biomedicínských časopisů.

$\Xi^{\prime}$

MUDr. Lumir Kunovsky

Department of Surgery

Faculty of Medicine,

Masaryk University

University Hospital Brno

Jihlavska 20, 62500 Brno

Czech Republic

e-mail: lumir.kunovsky@gmail.com

Submitted/Obdrženo: 22. 8. 2017

Accepted/Prijiato: 29. 8. 2017 


\section{Souhrn}

Východiska: Ampulární adenokarcinom patří mezi vzácnější nádorová onemocnění trávicího traktu. U premaligních lézí převládá terapie endoskopická. Dle některých autorů i časné karcinomy (ohraničené na sliznici) je možné řešit endoskopicky. U maligních lézí postihujících hlubší vrstvu (submukózou počínaje) má zásadní význam léčba chirurgická. Cílem článku je podat současný pohled na možnosti chirurgické léčby nádorů Vaterské papily s prezentací vlastního souboru pacientů. Materiál a metody: V období let 2012-2016 podstoupilo celkem 17 pacientů resekční výkon pro nádor Vaterské papily. Pacienti absolvovali standardní stagingové vyšetření, byli předvedeni před multioborovou komisí a poté byli indikováni k chirurgickému resekčnímu výkonu. Mezi hlavní sledované parametry patřil typ operačního výkonu, 30denní morbidita a mortalita, histopatologický výsledek a následná onkologická léčba. K histologickému vyhodnocení resekátu po pankreatoduodenektomii (PD) byl užit Leedský protokol. Výsledky: U 9 pacientů byla provedena PD a v 8 př́padech transduodenální chirurgická ampulektomie (transduodenal surgical ampullectomy - TSA). TSA převažovala u polymorbidních pacientů. Ze všech histologických preparátů $(\mathrm{n}=17)$ byl u 4 pacientů zjištěn adenom s high-grade dysplazií, diagnóza adenokarcinomu byla stanovena ve 13 prípadech. Adjuvantní onkologickou léčbu následně podstoupilo 8 pacientů, z toho 2 pacienti adjuvantní chemoterapii a 6 pacientů kombinaci chemoradioterapie. Závěr: Premaligní léze Vaterské papily Ize převážně rešit endoskopicky. Pokud není možné technické provedení endoskopického výkonu, je indikována léčba chirurgická. Při průkazu adenokarcinomu je preferována PD. U rizikových a polymorbidních pacientů, kde není podezření na postižení spádových uzlin, připadá v úvahu i provedení TSA. Endoskopická ultrasonografie je metoda volby při stanovení stagingu nádorového onemocnění Vaterské papily a má významnou roli při volbě mezi provedením endoskopické, lokální chirurgické excize (TSA) nebo radikální resekce (PD). Výsledky našeho souboru pacientů prokazují oprávněnost provedení TSA především u starších a polymorbidních pacientů, kde v histologickém zpracování resekátu u těchto výkonů převažovaly časné T stadia s příznivějším gradingem tumoru.

\section{Klíčová slova}

adenokarcinom Vaterské papily - duodenum - endoskopická resekce - ampulektomie - pankreatoduodenektomie - chirurgie

\section{Introduction}

Ampullary adenocarcinoma belongs to less frequent tumors with an incidence around $0.2 \%$ of all gastrointestinal cancers; however, it remains the second most common periampullary malignancy (after pancreatic carcinoma) [1-3]. In contrast to non-ampullary neoplasms, certain ampullary tumors may present early with obstructive jaundice or pancreatitis [4]. With an increasing role of endoscopy, most premalignant lesions of the ampulla of Vater can be resolved endoscopically. When just the major papilla is resected endoscopically, the right term for the procedure should be - endoscopic papillectomy $[5,6]$.

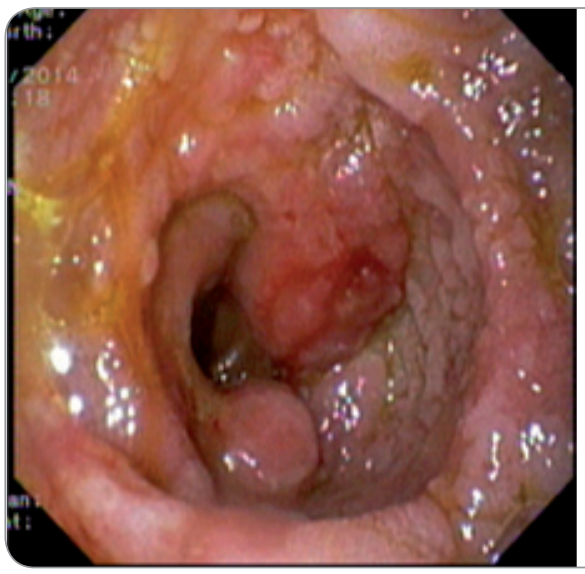

Fig.1. Endoscopic view of the ampullary tumor.

Some authors claim that early adenocarcinoma of the ampulla of Vater, without invasion to submucosa, can be very selectively treated endoscopically $[5,7]$. Mandatory staging is required - abdomen CT and endoscopic ultrasonography (EUS) to exclude spreading to the bile duct or pancreatic duct. However, the procedure should be performed by an experienced endoscopist, and if it is technically not possible, it should be referred to surgery.

The entire area of ampulopapillary complex can be removed only by surgerytransduodenal surgical ampullectomy (TSA) [6]. The procedure is finished by the reinsertion of the common bile duct and

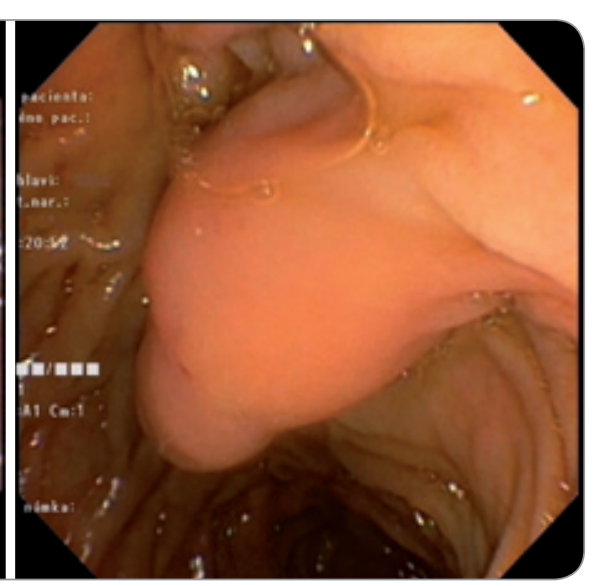

\section{Material and methods}

Between 2012 and 2016, 17 patients underwent resection of the tumor of the ampulla of the Vater at the Department of Surgery University Hospital Brno. All patients underwent endoscopy (Fig. 1) with a biopsy and a standard staging (abdomen CT (Fig. 2A, 2B), chest $X$-ray and endoscopic ultrasonography (Fig. 3)).

The patients were presented to a multidisciplinary committee and indicated for surgery. The surgical procedure was either local resection - TSA (Fig. $4 \mathrm{~A}, 4 \mathrm{~B})$ or PD. TSA was preferred in the early tumor stage or in polymorbid 

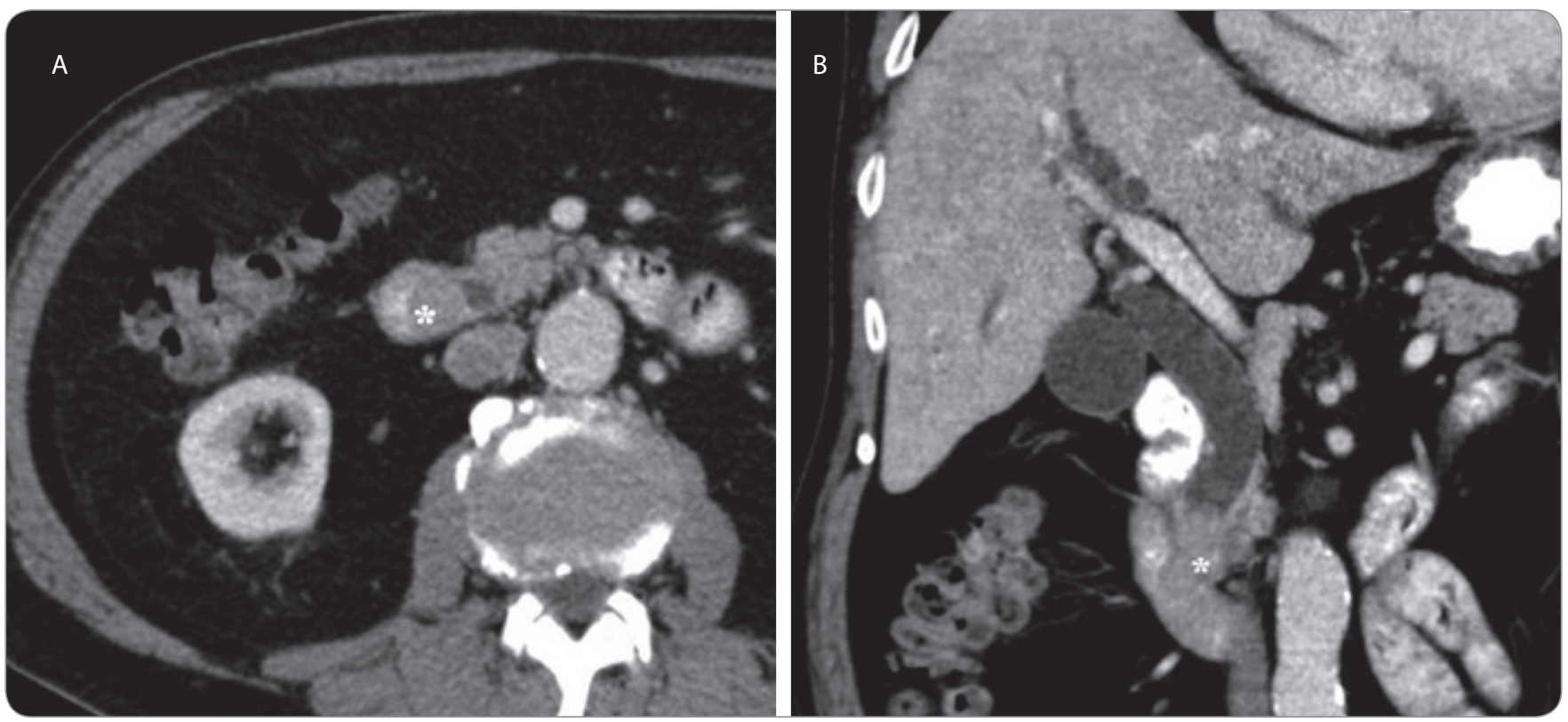

Fig. 2. An invasive ampullary carcinoma.

A. Contrast enhanced CT, portal venous phase. A homogeneous enhancing soft tissue mass (asterisk) protruding to lumen of duodenum.

B. Coronal multiplanal reconstruction shows polypoid like periampullary tumor (asterisk) obstructing distal common bile duct. Note the upstream dilatation of common bile duct and intrahepatic bile ducts.

patients. The main retrospectively measured parameters besides the type of surgery were: 30 days morbidity and mortality rate, definitive histologic result (lymph node metastasis, tumor grading, resections margins, perineural, angio or lymphovascular invasion) and subsequent oncologic therapy. Specimens after PD were dissected according to the standardized Leeds Pathology Protocol (LEEPP). Exclusion criteria were patients with inoperable local advanced tumor spreading or presence of distant metastases.

A literature research taking into account the last 15 years was performed (in MEDLINE, PubMed and Google Scholar databases). Studies and reviews focusing on diagnostics, endoscopic and mainly surgical treatment of the ampullary adenocarcinomas were searched.

\section{Results}

A total of 17 patients who underwent surgical resection of tumorous neoplasia of ampulla of the Vater were included. The group of patients consisted of 8 males and 9 females, with an average age 62.8 years. In total, $47 \%$ of the patients

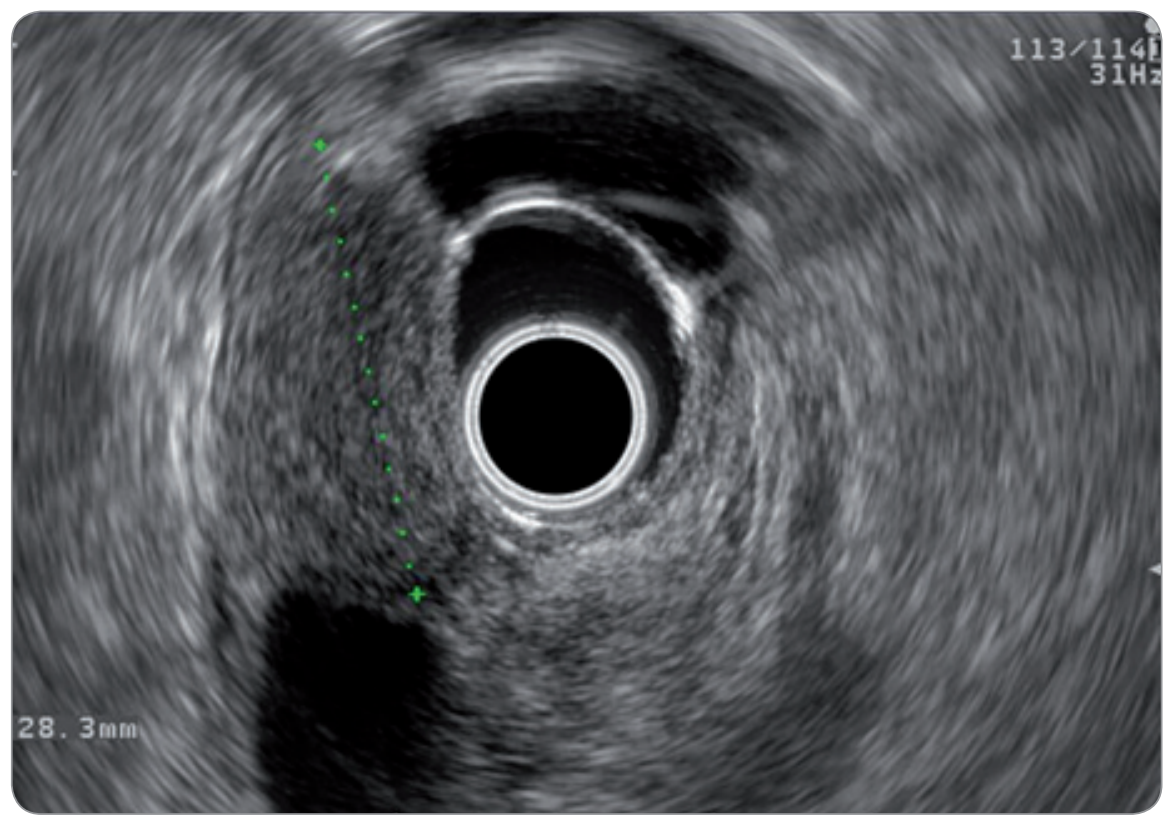

Fig. 3. Endoscopic ultrasonography view of the ampullary tumor.

were classified as ASA I-II (American Society of Anesthesiologist risk score), $53 \%$ of the patients as ASA III-IV. Basic characteristics of the patients are summarized in Tab. 1.

TSA was performed in 8 patients and PD in 9 cases. The histology section showed the diagnosis of adeno- ma with high-grade dysplasia (Fig. 5A) in 4 patients, in 13 cases the adenocarcinoma of ampulla of the Vater was confirmed (Fig. 5B). All patients with adenoma with high-grade dysplasia underwent TSA. Another 4 patients treated with TSA had adenocarcinomas in early $\mathrm{T}$ stage or in stage $\mathrm{T} 2(3 \times \mathrm{T} 1$, 


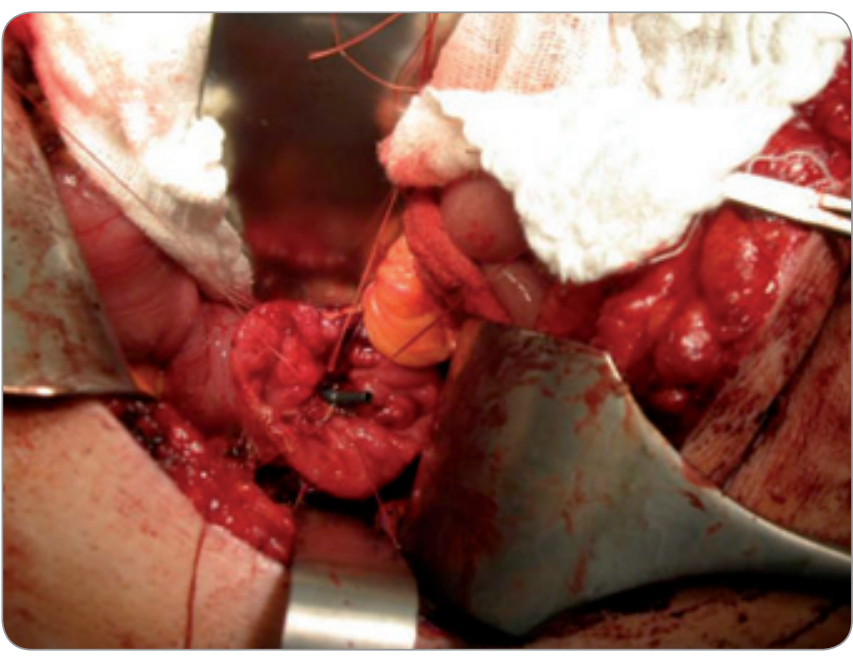

Fig. 4A. Intraoperative view during transduodenal surgical ampullectomy - duodenal incision.

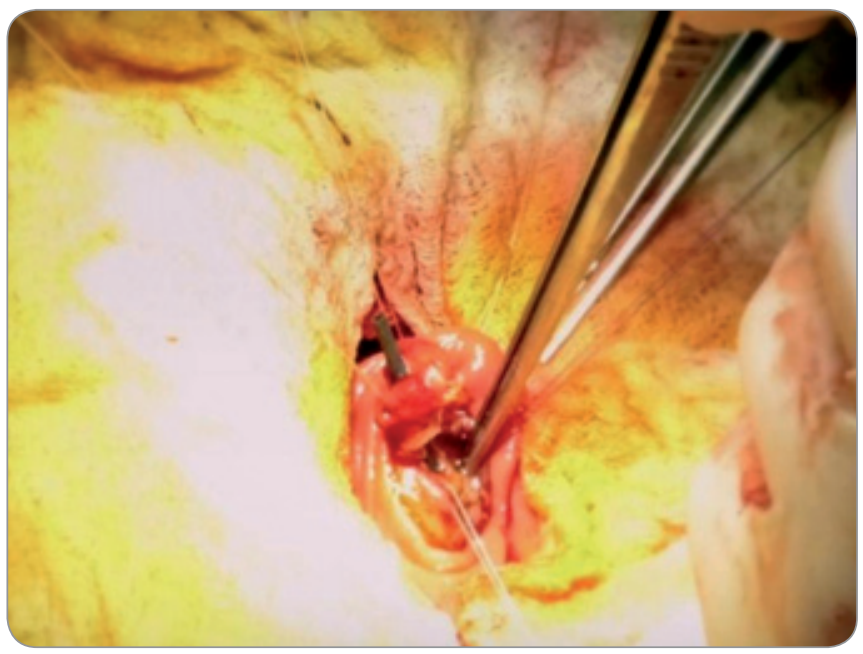

Fig. 4B. Intraoperative view during transduodenal surgical ampullectomy after resection of the tumor with duodeno-biliary stent.

Tab. 1. Basic characteristics of patients.

\begin{tabular}{l|l}
\hline $\begin{array}{l}\text { Variable } \\
\text { sex }\end{array}$ & Number of cases, $\mathbf{n}=\mathbf{1 7}(\%)$ \\
\hline male & $8(47)$ \\
\hline female & $9(53)$ \\
\hline age & $62.8^{*}$ \\
BMI & $27.8^{*}$ \\
\hline ASA & $8(47)$ \\
\hline I-II & $9(53)$ \\
III-IV & \\
\hline * average \\
$\begin{array}{l}\text { BMI - body mass index, ASA - American Society of Anesthe- } \\
\text { siologist risk score }\end{array}$
\end{tabular}

Tab. 2. Histology results, total number of adenocarcinomas $(n=13)$.

\begin{tabular}{|l|c|c|}
\hline Variable & $\begin{array}{c}\text { Ampul- } \\
\text { lectomy } \\
\text { (n= } \mathbf{4})\end{array}$ & $\begin{array}{c}\text { Pancreatico- } \\
\text { duoden- } \\
\text { ectomy (n=9) }\end{array}$ \\
\hline T-stage & 3 & 1 \\
\hline T1 & 1 & 3 \\
\hline T2 & 0 & 3 \\
\hline T3 & 0 & 2 \\
\hline T4 & & 2 \\
\hline grade & 3 & 6 \\
\hline well & 1 & 2 \\
\hline moderately & 0 & \\
\hline poorly/undifferentiated & 0 & 0 \\
\hline LN (examined) & & 2 \\
\hline $1-5$ & - & 2 \\
\hline $6-10$ & - & 4 \\
\hline $11-15$ & - & 1 \\
\hline $16-20$ & - & \\
\hline$\geq 21$ & - & \\
\hline
\end{tabular}

\section{LN (positive)}

\begin{tabular}{|l|l|l|}
\hline $1-5$ & - & 5 \\
\hline $6-10$ & - & 1 \\
\hline $11-15$ & - & 0 \\
\hline $16-20$ & - & 0 \\
\hline$\geq 21$ & - & 0 \\
\hline
\end{tabular}

\section{LN}

examined (median/ average)

positive (median/ average)

\section{tumor invasion}

\begin{tabular}{|l|l|l|}
\hline vascular & 0 & 0 \\
\hline lymphatic & 1 & 0 \\
\hline perineural & 0 & 1 \\
\hline
\end{tabular}

\section{resection margins}

\begin{tabular}{l|l|l|} 
positive & 0 & 0 \\
negative & 4 & 9
\end{tabular}

LN - lymph node 


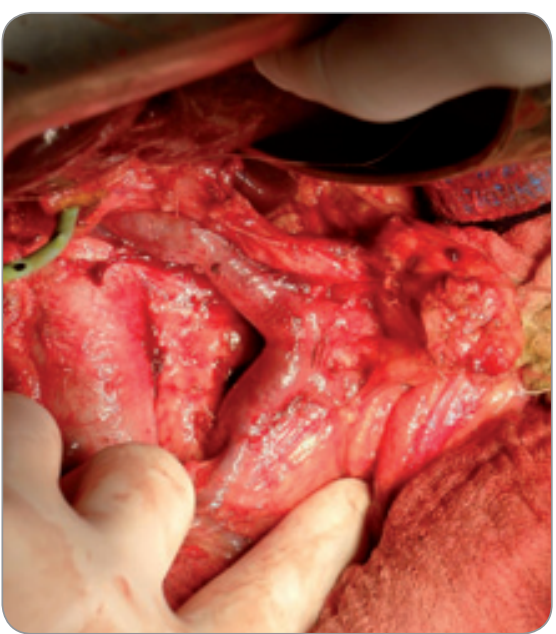

Fig. 6. Intraoperative view post resection phase of pancreaticoduodenectomy with standard lymphadenectomy.

long-term survival rate, even though it is still connected with high post-operative complications and mortality rate. Contrary to PD, TSA presents a less invasive method with a reduced morbidity and mortality. Nevertheless, lymphadenectomy is not performed during TSA, and the patient can have an increased risk of lymph node metastasis and recurrence of the disease.

Due to an earlier clinical presentation of ampullary adenocarcinomas, resection rates for most patients are much higher than other periampullary carcinomas. Curative surgery is possible in approximately $80 \%$ of cases at the time of diagnosis of ampullary cancer compared to pancreatic adenocarcinoma where the resectability rate is around $20 \%[3,12]$. The resectability in the case of $\mathrm{PD}$ procedure depends on exclusion of the metastatic dissemination and spreading to surrounding organs and arteries (superior mesenteric artery, coeliac trunk) [10]. Ampullary adenocarcinoma has a better long-term prognosis when compared to pancreatic adenocarcinoma or extrahepatic bile duct carcinoma [13] Choi et al. [14] reported a $59.9 \%$ overall 5 -year survival rate after $\mathrm{R} 0$ resection. The reason seems to be due a higher resectability rate and less aggressive tumor characteristics comparison to other periampullary cancer $[3,15,16]$.

The extend and radicality of the resection in the case of ampullary adenocarcinomas has been discussed in recent years. Due to its low incidence, it is difficult to perform a prospective study with a large number of patients. Few authors consider TSA feasible in $\mathrm{T} 1 / \mathrm{T} 2$ stage, with a maximum tumor size of $2 \mathrm{~cm}$ or less and without lymph node metastasis $[2,17,18]$.

Most authors recommend a radical PD in $\mathrm{T} 1$ stage due to a high risk of lymph nodes metastasis $[2,19,20]$. In 2015 , Lee et al. [21] reported a high local recurrence rate after TSA in T1 stage and therefore indicated TSA as unsuitable. The rate of lymph node metastasis was $10 \%$ after PD in $\mathrm{T} 1$ stage.

Negative prognostic factors for longterm survival have been reported as an advanced T stage, poorly differentiated tumor and perineural or perivascular spreading [3,21]. However, most authors coincide that positive lymph node involvement seems to be the most important factor for long-term survival in patients after resection for ampullary adenocarcinoma [3,14,19,22].

Lymphadenectomy is performed during the PD procedure (Fig. 6), and due to this evidence, PD seems to be superior in long-term survival against TSA [14]. Moreover, in our group of performed PD, we observed a metastatic lymph node involvement in high number, specifically in $70 \%$.

The specimens after PD were evaluated according to a LEEPP $[23,24]$. The high number of total examined lymph nodes (median 16) in our group seems to be due to LEEPP and its using the axial slicing technique [25]. In our group of ampullary adenocarcinoma, we achieved $\mathrm{R} 0$ resection in all PD specimens, which corresponds with the article published by Menon et al. [26], where $\mathrm{R} 1$ resection rate was significantly lower in ampullary adenocarcinoma compared to pancreatic cancer.

Otherwise, PD is still associated with a high rate of post-operative morbidity and mortality. Even in high-volume centers, mortality of pancreatobiliary surgery is around 5\% [27]. The most severe post-operative complications after PD are pancreatic fistula and postoperative bleeding. Despite improved surgical techniques, morbidity after PD is nowadays reaching up to $60 \%[10,20]$. Morbidity rate in our group of performed PD was $44 \%$ (four patients had a postoperative complication in PD group). In our group of patients, the rate of post-operative complications between TSA and PD seems to be comparable, although mortality rate was higher in PD group. However, because of a small patient cohort, this value cannot be evaluated as significant.

TSA presents a less radical surgical procedure, with reduced post-operative complications and mortality rate compared to PD $[2,20]$. Due to lower mortality and morbidity, TSA should be considered individually in elderly or polymorbid patients $[2,18,20]$.

In periampullary tumors EUS is superior to $\mathrm{CT}$ in evaluating $\mathrm{T}$ stage, regional lymph node metastasis or major vascular invasion, therefore EUS is crucial for deciding between endoscopic or surgical treatment $[5,6,28-30]$. Also, EUS (Fig. 3) had a crucial role in deciding if TSA is feasible in our group of patients or PD is necessary due to an advanced $T$ stage or regional lymph node metastasis. CT is rather favorable in excluding distant metastasis.

As mentioned previously, ampullary adenocarcinoma is a less frequent malignancy of gastrointestinal tract. Due to the rarity of the disease, there are no estimated clear guidelines for adjuvant treatment of the adenocarcinoma of the ampulla of Vater by oncologic committees [31]. Moreover, approaches are different in the US and in Europe. Adjuvant oncologic therapy should be considered if risk factors occur (positive lymph nodes, positive resection margins, unfavorable grading, perineural, angio or lymphovascular invasion) [3,12]. With regard to TNM staging, tumor grade, angio or lymphagio invasion, resection margins, performance status and experiences of the oncologic center, adjuvant chemotherapy or chemoradiotherapy must be always considered [31]. Nevertheless, it is necessary to approach each patient individually, taking into account his overall health condition, polymorbidity and patient's choice. From our group of 13 patients with adenocarcinoma, 
8 patients had adjuvant oncologic therapy, out of which 2 underwent chemotherapy and 6 a combination of chemoradiotherapy.

Ampullary adenocarcinoma can be divided histopathologically into intestinal and pancreaticobiliary subtype. This seems to be a significant prognostic factor [31,32]. Chang et al. [32] in his cohort showed prognostic diversity in these subtypes. Patients with histomolecular pancreaticobiliary phenotype had a poor prognostic outcome. Patients from the group of intestinal phenotype without lymph node metastasis achieved on the contrary an excellent prognosis.

Another new study is pointing to a mutational status of KRAS in predicting a poor outcome in ampullary adenocarcinoma patients. Especially KRAS ${ }^{G 12 D}$ mutations were connected with a worse prognosis, and the authors noted that these patients may benefit from adjuvant therapy [33].

The limitations of our presented study are retrospective data collection, total number of patients and impossibility to evaluate a long-term survival rate due to a short observation interval. However, caused by the rarity of this diagnosis, we consider these data as relevant to share.

\section{Conclusion}

Ampullary adenocarcinomas have a better long-term survival than other tumors from the subhepatic area (pancreas, bile duct). Due to their earlier clinical presentation, curative resection rate is higher. PD remains a standard and is recommended as the surgical treatment of ampullary adenocarcinoma. TSA is suitable in premalignant lesions. In high-risk or polymorbid patients, TSA is feasible in early tumor stage (T1/T2). EUS is significant in decision making of the surgical type of procedure (TSA or PD).

\section{References}

1. Duffy JP, Hines OJ, Liu JH et al. Improved survival for adenocarcinoma of the ampulla of Vater: fifty-five consecutive resections. Arch Surg 2003; 138(9): 941-950. doi 10.1001/archsurg.138.9.941

2. Feng J, Zhou X, Mao W. Prognostic analysis of carci noma of the ampulla of Vater: pancreaticoduodenec tomy versus local resection. Hippokratia 2012; 16(1): 23-28.

3. Klein F, Jacob D, Bahra M et al. Prognostic factors for long-term survival in patients with ampullary carcinoma: the results of a 15-year observation period after panc reaticoduodenectomy. HPB surgery 2014; 970234. do 10.1155/2014/970234.

4. Pittayanon R, Imraporn B, Rerknimitr R et al. Advances in diagnostic endoscopy for duodenal, including ampullary, adenoma. Dig Endosc 2014; 26 (Suppl 2): 10-15. doi: 10.1111/den.12244

5. De Palma GD. Endoscopic papillectomy: Indications, techniques, and results. World J Gastroenterol 2014; 20(6) 1537-1543. doi: 10.3748/wjg.v20.i6.1537.

6. Gaspar JP, Stelow EB, Wang AY. Approach to the endoscopic resection of duodenal lesions. World J Gastroenterol 2016; 22(2): 600-617. doi: 10.3748/wjg.v22.i2.600. 7. Kakushima $\mathrm{N}$, Kanemoto $\mathrm{H}$, Tanaka M et al. Treatment for superficial non-ampullary duodenal epithelial tumors. World J Gastroenterol 2014; 20(35): 12501-12508. doi 10.3748/wjg.v20.i35.12501.

8. Schneider L, Contin P, Fritz S et al. Surgical ampullec tomy: an underestimated operation in the era of endoscopy. HPB 2016; 18(1): 65-71. doi: 10.1016/j.hpb.2015.07. 004

9. Ceppa EP, Burbridge RA, Rialon KL et al. Endoscopic versus surgical ampullectomy: an algorithm to treat disease of the ampulla of Vater. Ann Surg 2013; 257(2): 315-322. doi: 10.1097/SLA.0b013e318269d010.

10. Ryska M, Hrabal P. Malignant tumours of the duodenum. Rozhl Chir 2015; 94(12): 497-503.

11. Dindo D, Demartines N, Clavien PA. Classification of surgical complications: a new proposal with evaluation in a cohort of 6336 patients and results of a survey. Ann Surg 2004; 240(2): 205-213.

12. Ahn DH, Bekaii-Saab T. Ampullary cancer: an overview. Am Soc Clin Oncol Educ Book 2014; 112-115. doi 10.14694/EdBook AM.2014.34.112.

13. Dusek L, Muzik J, Maluskova D et al. Cancer incidence and mortality in the Czech Republic. Klin Onkol 2014 27(6): 406-423. doi: 10.14735/amko2014406.

14. Choi SB, Kim WB, Song TJ et al. Surgical outcomes and prognostic factors for ampulla of Vater cancer. Scand J Surg 2011; 100(2): 92-98. doi: 10.1177/145749691110000 205.

15. Sudo T, Murakami Y, Uemura K et al. Prognostic impact of perineural invasion following pancreatoduodenec tomy with lymphadenectomy for ampullary carcinoma. Dig Dis Sci 2008; 53(8): 2281-2286. doi: 10.1007/s10620 007-0117-6

16. Qiao Q, Zhao Y, Ye M et al. Carcinoma of the ampulla of Vater: factors influencing long-term survival of $127 \mathrm{pa}-$ tients with resection. World J Surg 2007; 31(1): 137-143. doi: 10.1007/s00268-006-0213-3.

17. Gao Y, Zhu Y, Huang $X$ et al. Transduodenal ampullectomy provides a less invasive technique to cure early ampullary cancer. BMC Surg 2016; 16(1): 36. doi: 10.1186/s12893-016-0156-z

18. Ostojic SM, Knezevic DR, Perisic M et al. The importance of choice of resection procedures in $\mathrm{T} 1$ and T2 stage of carcinoma of the ampulla of Vater. J BUON 2015; 20(5): 1206-1214

19. Amini A, Miura JT, Jayakrishnan TT et al. Is local resection adequate for T1 stage ampullary cancer? HPB 2015; 17(1): 66-71. doi: 10.1111/hpb.12297.

20. Song J, Liu H, Li Z et al. Long-term prognosis of surgical treatment for early ampullary cancers and implications for local ampullectomy. BMC Surg 2015; 15: 32. doi: 10.1186/s12893-015-0019-z

21. Lee H, Park JY, Kwon W et al. Transduodenal ampullectomy for the treatment of early-stage Ampulla of Vater Cancer. World J Surg 2016; 40(4): 967-973. doi: 10.1007/s00268-015-3316-X

22. Solaini $L$, Jamieson NB, Metcalfe $M$ et al. Outcome after surgical resection for duodenal adenocarcinoma in the UK. Br J Surg 2015; 102(6): 676-681. doi: 10.1002/bjs. 9791.

23. Verbeke CS, Leitch D, Menon KV et al. Redefining the $\mathrm{R} 1$ resection in pancreatic cancer. Br J Surg 2006; 94(1): 1232-1237. doi: 10.1002/bjs.5738

24. Hlavsa J, Prochazka V, Mazanec J et al. Standardization of pancreatic cancer specimen pathological examination. Rozhl Chir 2014; 93(3): 132-138.

25. Verbeke CS, Menon KV. Redefining resection margin status in pancreatic cancer. HPB 2009; 11 (4): 282-289. doi: 10.1111/j.1477-2574.2009.00055.x.

26. Menon KV, Gomez D, Smith AM et al. Impact of margin status on survival following pancreatoduodenectomy for cancer: the Leeds Pathology Protocol (LEEPP). HPB 2009; 11(1): 18-24. doi: 10.1111/j.1477-2574.2008.00013.x.

27. Hariharan D, Saied A, Kocher HM. Analysis of mortality rates for pancreatic cancer across the world. HPB 2008; 10(1): 58-62. doi: 10.1080/13651820701883148.

28. Chathadi KV, Khashab MA, Acosta RD et al. The role of endoscopy in ampullary and duodenal adenomas. Gastrointest Endosc 2015; 82(5): 773-781. doi: 10.1016/j. gie.2015.06.027.

29. Askew J, Connor S. Review of the investigation and surgical management of resectable ampullary adenocarcinoma. HPB 2013; 15(11): 829-838. doi: 10.1111/hpb.12038.

30. Kunovský L, Kala Z, Hlavsa J et al. Tumory duodena jako vzácná diagnóza - naše zkušenosti za posledních 5 let. XL. brněnské onkologické dny a XXX. konference pro nelékařské zdravotnické pracovníky 27.-29. 4. 2016, Brno Klin Onkol 2017; 30 (Suppl 1): S94.

31. Ghosn M, Kourie HR, El Rassy E et al. Where does chemotherapy stands in the treatment of ampullary carcinoma? A review of literature. World J Gastrointest Oncol 2016; 8(10): 745-750. doi: 10.4251/wjgo.v8.i10. 745.

32. Chang DK, Jamieson NB, Johns AL et al. Histomolecular phenotypes and outcome in adenocarcinoma of the ampulla of Vater. J Clin Oncol 2013; 31(10): 1348-1356. doi: $10.1200 / J C O .2012 .46 .8868$.

33. Valsangkar NP, Ingkakul T, Correa-Gallego C et al. Survival in ampullary cancer: potential role of different KRAS mutations. Surgery 2015; 157(2): 260-268. doi: 10.1016/j. surg.2014.08.092. 